\title{
THE RIGHT TO LEGAL ASSISTANCE IN INTERNATIONAL LAW, WITH SPECIAL REFERENCE TO THE ICCPR, THE ECHR AND THE ACHR
}

Charika Marasinghe*

\section{INTRODUCTION}

The right to legal assistance is of such fundamental importance that all other rights which are relevant for the due conduct of a fair trial may be worthless if this right is not respected. Rights such as adequate time and facilities for the preparation of the defence, free assistance of an interpreter and examination of witnesses could be meaningless if the accused is not given the right to legal assistance. When confronted with the vast resources and advantages which the prosecution usually enjoys, especially in criminal cases in which the state is involved, it is only legal assistance that will help the accused to vindicate his or her case. Thus international law relating to human rights has come to accept an inalienable right to legal assistance, as a paramount consideration in the context of the concept of fair trial.

\section{THE MEANING OF THE RIGHT TO 'LEGAL ASSISTANCE'}

First it is necessary to examine the difference in the terminology regarding the right to legal assistance used in the International Covenant on Civil and Political Rights, the European Convention for the Protection of Human Rights and Fundamental Freedoms and the American Convention on Human Rights. ${ }^{1}$ This will facilitate a clear understanding of the case law on the interpretation of the right to legal assistance.

Article 14(3)(d) of the ICCPR reads:

\footnotetext{
* Attorney-at-law; Senior Lecturer in Law, Faculty of Law, University of Colombo, Sri Lanka.

${ }^{1}$ Hereinafter referred to respectively as ICCPR, ECHR and ACHR.

Asian Yearbook of International Law, Volume 5 (Ko Swan Sik et al., eds.; 90-411-0375-9

(c) 1997 Kluwer Law International; printed in the Netherlands), pp. 15-44
} 
"In the determination of any criminal charge against him, everyone shall be entitled to [. . .] be tried in his presence, and to defend himself in person or through legal assistance of his own choosing; to be informed, if he does not have legal assistance, of this right; and to have legal assistance assigned to him, in any case where the interests of justice so require, and without payment by him in any such case if he does not have sufficient means to pay for it."

Article $6(3)(c)$ of the ECHR which was mainly based on an earlier draft of the ICCPR, reads:

"Everyone charged with a criminal offence has [the right] to defend himself in person or through legal assistance of his own choosing or, if he has not sufficient means to pay for legal assistance, to be given it free when the interests of justice so require."

And finally, Article 8(2) of the ACHR refers to:

“(d) the right of the accused to defend himself personally or to be assisted by legal counsel of his own choosing, and to communicate freely and privately with his counsel;

(e) the inalienable right to be assisted by counsel provided by the state, paid or not as the domestic law provides, if the accused does not defend himself personally or engage his own counsel within the time period established by law."

All three instruments guarantee to an accused the right to defend himself in person or through legal assistance of his own choosing. The principal differences between the quoted provisions are, first, that the ICCPR goes further than the ECHR and ACHR in emphasizing the right of accused persons to be informed of their right to legal assistance if they do not already have it. Secondly, under the ICCPR, unlike the other conventions, accused persons have a right to have legal assistance assigned to them "in any case where the interests of justice so require" and without payment by him "in any such case if he does not have sufficient means to pay for it". The ECHR makes provision for free legal assistance only if "the accused has not sufficient means to pay for legal assistance" and "when the interests of justice so require". Unlike the ICCPR, it does not assure accused persons a right to have free legal assistance on every occasion where they do not have sufficient means but only "where the interests of justice so require". The ECHR is also silent about legal assistance in case the accused persons are politically or otherwise unpopular. 
What happens to them in the event of their being unable to find a lawyer remains obscure in the ECHR.

The wording of the ACHR in this respect is substantially different from the ICCPR and the ECHR. According to the ACHR accused persons are entitled to be assisted by counsel provided by the state, paid or not as the domestic law provides, in two instances: if the accused does not defend himself personally or engage his own counsel within the time period established by law. It may reasonably be assumed that the phrase "does not engage his own counsel within the time period established by law" is broad enough to cover the two instances where accused persons are without means to pay for a lawyer and where the accused persons are unable to find a lawyer due to their being politically or otherwise unpopular. On the other hand, the question whether the state will pay for such assistance depends upon the domestic law of the state concerned. This qualification cannot be found in the ICCPR or ECHR.

The wording of article 14 (3)(d) of the ICCPR seems the most satisfactory of the three conventions on this point since it encompasses the widest possible range of cases and there is an implicit guarantee that no accused should remain without legal assistance for any reason. The miscarriage of justice that is inherent in any trial in which the accused is without legal assistance cannot be countenanced by any civilized society and its prevalence would exert a demoralizing impact on the subjective assessment of members of the society, whatever may be the objective outcome of the trial.

Finally, only the ICCPR and the ACHR guarantee the right of communication between the lawyer and the accused. The ECHR is silent on this point. However, the case law of the European Commission on Human Rights and the European Court of Human Rights ${ }^{2}$ rectifies this omission.

\subsection{Lawyer or legal assistance?}

In order to decide whether the conventions guarantee the accused a right to be represented by a professionally qualified lawyer or merely to obtain legal assistance, it is necessary to go back to the preparatory work of the United Nations Commission on Human Rights ${ }^{3}$ which was entrusted with the task of drafting the ICCPR. ${ }^{4}$

\footnotetext{
${ }^{2}$ Hereinafter referred to respectively as the European Commission and the European Court.

${ }^{3}$ Hereinafter referred to as the UNCHR.

${ }^{4}$ No useful discussion pertaining to this right is found in the travaux preparatoires of the ECHR and the ACHR.
} 
At an early stage in the drafting the phrase 'aid of counsel' was suggested ${ }^{5}$ and the intention was to refer to "representation by a barrister". ${ }^{6}$ However, at a later stage, the term 'qualified representative' was used, which was defined as covering "anyone assumed by the appellant to be qualified". ${ }^{7}$ But as this could have meant "qualified as a lawyer", the phrase 'legal assistance' which appears in the final text was introduced because, in the words of the United Kingdom delegate Ms. BowIE, "it did not necessarily mean a lawyer, but merely assistance in the legal conduct of a case. Under Moslem Law or in cases judged according to native law and custom the compulsory assistance of a lawyer might give rise to difficulties". ${ }^{8}$

From the instruments of ratification of several countries it is evident that lack of lawyers and the non-existence of a bar often prevent the implementation of the right to legal assistance to its maximum extent. ${ }^{9}$ For example, the representative of the United Kingdom reported to the UNCHR that in St. Helena there were no lawyers in private practice. There was, however, a developed system of 'Mackenzie men' and any person charged with a criminal offence could usually obtain lay assistance in the preparation and conduct of his defence. In St. Helena the courts were used to dealing with unrepresented defendants and the court itself would assist an unrepresented defendant in ensuring that justice was done. Therefore it is appropriate to interpret 'legal assistance' in a wider sense, in order to cover situations of this nature.

One can discern a similar wide interpretation of the term legal assistance in the decisions of the European Commission. In $X$ v. $F R G^{10}$ the applicant alleged that he was represented at his trial not by counsel appointed by the court to defend him, but by a 'Gerichtsreferendar', who is a jurist employed by the Government. A 'Gerichtsreferendar' is a probationer undergoing statutory training. In its decision the European Commission observed that:

\footnotetext{
${ }^{5} \mathrm{E} / \mathrm{CN} .4 / 21$.

${ }^{6} \mathrm{E} / \mathrm{CN} .4 / \mathrm{AC} .3 / \mathrm{SR} .5$ p. 5.

${ }^{7}$ E/CN.4/SR.5, 6.

${ }^{8}$ E/CN.4/SR.107, p. 6; see also UN Seminar on the Protection of Human Rights in Criminal Law and Procedure UN Doc. ST/TAA/HR/2 at p. 16 (1958).

${ }^{9}$ The UK in its instrument of ratification reserved the right not to apply or not to apply in full the guarantee of free legal assistance in sub-paragraph (d) of paragraph 3 of Article 14 in so far as the shortage of legal practitioners renders the application of this guarantee impossible in the British Virgin Islands, the Cayman Islands, the Falkland Islands, the Gilbert Islands, the Pitcairn Islands Group, St. Helena and Dependencies and Tuvalu; see also Rwanda, CCPR/C/SR.782 p. 8.

${ }^{10}$ No. 509/59, 3 ECHRYb (1959) 174 at 180-182.
} 
"... whereas the preparatory works on Article 6(3)(c) confirm that the word 'avocat' (french text) is not to be understood in the technical sense of the term but in the sense of 'legal assistance', whereas in the case in question, although it is clear that 'Gerichtsreferendar', is not an 'avocat', he is, nevertheless, a competent 'defenseur', when instructed to provide the accused with 'legal assistance'."11

The use of the words "assisted by legal counsel" in the ACHR precludes any possibility of such a broader interpretation. Thus it is doubtful whether a person other than a duly qualified lawyer could defend the accused under the ACHR.

However, the most important question to be determined in this connection relates to the extent to which a broad interpretation protects the accused person's right to an effective defence. A lawyer's role in a criminal trial is vital and the advantages of representation by a trained lawyer are immense. No lay person, no matter how well informed and self possessed, has such resources of knowledge, training and skill as are especially the attributes of the legal profession. These can bring real advantages to the defence at the stage of the principal examination: the defence lawyer may object to irrelevant, inadmissible and prejudicial evidence or to leading questions or improper production of documents or other exhibits. It bears remembering what THOMAS BURGENTHAL has said in this connection:

\footnotetext{
"Even assuming that the Commission is right in holding that Article 6(3)(c) does not require the assignment of an attorney, this does not relieve it of the duty to ascertain to what extent the individual in question did in fact provide meaningful legal assistance." 12
}

Several countries ${ }^{13}$ have reported to the United Nations Human Rights Committee $^{14}$ that representation by a lawyer is obligatory in their countries in the following instances:

(a) where the accused is a minor;

\footnotetext{
"Ibid. See further ALEC SAMUELS, 'The right to a fair trial, the European Convention on Human Rights', International Bar Journal (1972) 39; DAVID HARRIS, 'The right to a fair trial in criminal proceedings as a human right', 16 ICLQ (1967) 352.

${ }_{12}$ 'Comparative study of certain due process requirements of the European Human Rights Convention', 16 Buffalo Law Review (1966-67) 34.

${ }^{13}$ Japan CCPR/C/10/Add. p. 25; Yugoslavia CCPR/C/1/Add.23 p. 19; Poland CCPR/C/4/Add.2 p. 19; Senegal CCPR/C/Add.2 p. 18; Russia CCPR/C/28/Add.3; Mongolia CCPR/C/Add.2 p. 21; Hungary CCPR/C/SR.686 p. 5.

${ }^{14}$ Hereinafter referred to as UNHRC.
} 
(b) where the accused is not less than 70 years of age;

(c) where the accused is deaf or mute;

(d) where the accused is suspected to be insane or weak-minded.

\subsection{When does the right to legal assistance actually arise? Preliminary investigation stage or trial stage}

Neither the provisions relating to legal assistance in the ICCPR, ECHR and ACHR, nor their preparatory work indicate at what stage of the proceedings the right to legal assistance arises. The relevant provisions belong to a group of provisions which might be applicable at the trial itself as well as at a previous stage. ${ }^{15}$ Indeed, extending the right to legal assistance to cover the preliminary investigation stage is of great importance for two main reasons. First, the preliminary investigation stage determines the framework in which the offence charged will be considered at the trial. Secondly, there is a strong possibility that evidence obtained during the preliminary investigation stage will be relied on at the trial. Also the fact that the accused person may be subjected to intense questioning by the police cannot be ignored. In particular, confessions and admissions are very often made by the accused person at this stage of the proceedings. Thus he has to be very cautious in making statements during such questioning. ${ }^{16}$ Therefore, a lawyer's advice and assistance are essential and in the best interests of the accused at the preliminary investigation stage of the proceedings. It is essential for the defence that "the basis for its defence activity can be laid already at this stage. ${ }^{17}$

The UNHRC and the Inter-American Commission on Human Rights (IACHR) have not been called upon to give a ruling on whether the right to legal assistance arises at the preliminary investigation stage. The European Commission and the European Court did not answer this question specifically until 1984, when in Can v. Austria ${ }^{18}$ the European Commission, having regard to the particular facts of the case, expressed the view that the right to legal assistance as provided in Article 6(3)(c) of the ECHR could be applicable to preliminary investigations. Although the decision was based on the specific facts before the Commission, it may reasonably be assumed that the reasoning of the European Commission laid down the foundations for a general principle

\footnotetext{
${ }^{15}$ Can $v$. Austria (No. 9300/81), 96 Judgments and Decisions (1985) p. 14 para. 49.

${ }^{16} \mathrm{G} v$. UK No. 9370/81, 35 D.R. (1983) 75.

${ }^{17}$ Can $v$. Austria No. 9300/81, 96 Judgments and Decisions (1985) para. 50.

${ }^{18}$ Ibid.
} 
according to which the right to legal assistance as provided by Article 6(3)(c) would also apply to the preliminary investigation stage when the circumstances so demand. Similarly in Imbrioscia v. Switzerland ${ }^{19}$ the European Court was of the view that the manner in which Article 6(3)(c) is to be applied during the preliminary investigation depends on the special features of the proceedings involved and on the circumstances of the case.

Although the UNHRC has not yet dealt with this issue in considering individual applications, it has made some comments on the subject while examining state reports submitted by various countries. Mr. LALlAH, a member of the UNHRC stressed ${ }^{20}$ that it was particularly important to have a lawyer at the pre-trial stage of the proceedings. Mr. BoUZIRI, another member of the UNHRC, observed that in Venezuela an accused was not entitled to have a lawyer until the preliminary investigation had been concluded. ${ }^{21} \mathrm{He}$ went on to comment that it was not only a serious departure from the guarantees that should be afforded to the accused but was also in conflict with the Constitution of Venezuela. It is implicit in these comments that under the ICCPR the right to legal assistance was considered to cover the preliminary investigation stage. A number of states reported that in their countries the right to legal assistance is indeed available during the preliminary investigation stage. ${ }^{22}$

\section{LIMITATIONS OF THE RIGHT TO LEGAL ASSISTANCE}

\subsection{The right to defend oneself in person}

All three instruments give accused persons the right either to defend themselves in person or through legal assistance of their own choosing. Prima facie it appears that the provisions in the ICCPR, ECHR and ACHR give accused persons an option as to the way in which their defence should be assured, namely, whether to defend themselves in person or through legal assistance. In practice, however, certain limitations have been imposed on this

19 32/1992/377/45, 24 Nov. 1993, 275 Judgments and Decisions; Imbrioscia $v$. Switzerland (24 Nov. 1993), Ser. A No. 275; see also the case Granger $v$. the United Kingdom (28 March 1990), Ser. A No. 174 para. 44.

${ }^{20} \mathrm{CCPR} / \mathrm{C} / \mathrm{SR} .90$ p. 3.

${ }^{21} \mathrm{CCPR} / \mathrm{C} / \mathrm{SR} .248$.

${ }^{22}$ Sweden, CCPR/C/1/Add.9 p. 16; Czechoslovakia, CCPR/C/1/SR.66 p. 6; Byelorussia, CCPR/C/SR.199 p. 10; Bulgaria, CCPR/C/Add.30 p. 11; Ukrain, CCPR/C/SR.160; Mongolia, CCPR/C/37/Add.2 p. 21; Rumania, CCPR/C/32/Add.10 p. 21. 
right. The European Commission has repeatedly stated that all that is guaranteed by Article 6(3)(c) of the Convention is that proceedings against the accused will not take place without adequate representation for the defence, and that Article 6(3)(c) does not give accused persons the right to decide themselves in what manner their defence should be assured. ${ }^{23}$ This approach has given rise to certain ambiguities. These can be seen in the following decisions of the European Commission. In $X$ v. Austria the European Commission stated:

\begin{abstract}
"whereas the decisions as to which of the two alternatives mentioned in the paragraph should be chosen, namely, the applicant's right either to defend himself in person or to be assisted by a lawyer of his own choosing or in certain circumstances, one appointed by the court, rests with the respondent government." ${ }^{24}$
\end{abstract}

In another case between the same parties ${ }^{25}$ the European Commission stated that the decision rests with "the competent authorities". Yet in $X \mathrm{v}$. Norway ${ }^{26}$ it said the decision depended upon "applicable legislation or rules of court". It is submitted that the reasoning on which the decisions of the European Commission were based is contrary to the basic principles of fair trial. In a criminal trial the accused may want to defend himself in person. According to the plain words of Article 6(3)(c) of the ECHR it is the right of the accused himself or herself and thus the state cannot force the person to be defended by a lawyer. In the same manner, accused persons should have the right to choose a lawyer if they so wish, subject to the power of the state to regulate the appearance of lawyers. The state may be justified under certain circumstances to impose its preference in the interest of a fair trial. If, however, the state encroaches upon the right of the accused to choose without justification, the very ideas of justice and fair trial are undermined. The state may only come into the picture for giving effect to the provisions of the conventions.

\footnotetext{
${ }^{23} \mathrm{X} v$. UK (No. 7368/76, 2 May 1978, unpubl.).

${ }^{24}$ No. 1242/61, 24 Nov. 1962 (unpubl.).

${ }^{25}$ No. 2676/65, 23 ECHRC Coll. (1967) 31; X v. Austria No. 2645/65, 11 ECHRYb (1968) 322 at $350 ; \mathrm{X} v$. UK (No. 6683/74, 10 Dec. 1975, unpubl.).

${ }^{26}$ No. 5923/72, 3 D.R. (1975) 43 at 43-44.
} 


\subsection{Legal assistance of one's own choosing}

Although the accused is given the right to choose his or her own lawyer in unambiguous words by all three conventions, the travaux preparatoires reflect a diversity of opinions. Much of the confusion results from the question whether the right to choose their own lawyer should be conferred upon the accused persons, irrespective of their ability to pay for a lawyer. The members of the UNHRC did not reach a conclusion as to the exact meaning of the words 'own choosing' in Article 14(3)(d). The case law of the UNHRC is also silent in this respect. The European Commission has adopted a restrictive interpretation in respect of the words 'own choosing'. It has held, that "the Convention guarantees the right of an accused to legal assistance of his own choosing only where he has sufficient means to pay for such assistance." 27 Again in another case $^{28}$ the European Commission declared that "Article 6(3)(c) does not guarantee the right to choose an official counsel who is appointed by the court . . . nor does it guarantee a right to be consulted with regard to the choice of an official counsel". In Croissant v. Germany ${ }^{29}$ it was stated that the accused's right to be defended by counsel of his own choosing is necessarily subject to certain limitations in relation to free legal aid and, where it is for the courts to decide whether interests of justice require appointment, defendant's wishes must be considered. However, the courts can override those wishes when relevant and sufficient grounds exist for holding that this is necessary in the interests of justice. It is interesting to note that domestic courts have taken a similar view. ${ }^{30}$

The salient point which emerges from these decisions is that under the ECHR accused persons have the freedom to choose a lawyer only where they have the means to pay for a lawyer. This seems unsatisfactory, because an accused who does not have sufficient means should not be discriminated against on pecuniary grounds. Even if there might be practical difficulties in securing the lawyer the accused wants, still some degree of choice should be afforded to the accused in order to secure 'equality of arms' between the accused and the prosecution. Sir VINCENT EVANS, a member of the UNHRC, has also stated that even where the accused person received legal assistance

\footnotetext{
${ }^{27} \mathrm{X} v$. FRG No. $127 / 55,1$ ECHRYb (1956) 230 at 231; see also $\mathrm{X} v$. FRG No. 646/59, 3 ECHRYb (1960) 272; X v. Austria No. 4338/6936 ECHRCColl. (1970) p. 79 at 82.

${ }^{28} \mathrm{X} v$. FRG, No. 6946/75, 6 D.R. (1976) 114 at 116-117.

${ }^{29}$ 62/1991/314/385, 25 Sep. 1992, 237 Judgments and Decisions.

${ }^{30}$ Federal Republic of Germany, Bundesverfassungsgericht (Federal Constitutional Court), 16 December 1958.
} 
free of charge he should as far as possible choose his counsel himself. ${ }^{31}$ In some countries ${ }^{32}$ a list of official counsel is submitted to the accused, in order that he may choose one or more to act in his defence.

Nonetheless, where accused persons have the means to pay for a lawyer, their right to the lawyer of their own choice should be respected. Instances of violations of this right can be seen in several applications that came before the UNHRC. In all these cases ${ }^{33}$ the free choice of defence counsel was prevented by the systematic harassment of lawyers who tried to take up the cases of political prisoners and finally the accused were forced to accept ex officio legal counsel. It should be noted that in all these cases the accused had the means to pay for a lawyer. Accordingly the UNHRC declared a violation of Article 14(3)(d) by the state concerned. However, the UNHRC has also stated that Article 14(3)(d) does not entitle the accused to choose counsel provided to him free of charge ${ }^{34}$. In another case the UNHRC said that although Article 14(3)(d) does not entitle the accused to choose counsel provided to him free of charge, measures must be taken to ensure that counsel, once assigned, provides effective representation in the interests of justice. ${ }^{35}$

In Cases No. 8094, 9038 and 9080 the IACHR found a violation of this right by the government of Guatemala. ${ }^{36}$ These cases concerned several persons executed by firing squads in Guatemala. They had been denied the right to be duly assisted by a defence counsel of their choice, and the IACHR held that this was contrary to the universally accepted rules of due process. The IACHR has received a number of complaints alleging acts of violence against members of the legal profession. There have been reports of the

${ }^{31}$ CCPR/C/SR.425 p. 9.

${ }^{32}$ E.g., New Zealand, CCPR/C/10/Add.13; Mexico, CCPR/C/22/Add.1 p. 20; Austria, CCPR/C/6/Add.7.

${ }^{33}$ Delia Saldias de Lopoz v. Uruguay No. R. 12/152, UN doc. A/36/40 p. 176; Lilian Celiberti de Caseriego $v$. Uruguay No. 13/56, UN doc. A/36/40 p. 185; Alba Pietraroia $v$. Uruguay No. R. 10/44, UN doc. (A/36/40) p. 157; Teti Tsquierdo $v$. Uruguay No. R. 18/73, UN doc. A/37/40 p. 179; Vasiliskis $v$. Uruguay No. 80/1980, UN doc. A/38/40 p. 173; Viena Acosta $v$. Uruguay No. 110/1981, UN doc. A/39/40 p. 169; Marais $v$. Madagascar No. 49/1979, UN doc. A/38/40 p. 14; Conteris $v$. Uruguay No. 139/1983, UN doc. A/40/40 p. 196; Drescher Caldas v. Uruguay No. 43/1979, UN doc. A/38/40 p. 192.

${ }^{34}$ Aston Little $v$. Jamaica No. 283/1988, UN doc. A/47/40 p. 268 at 275.

${ }^{35}$ Irvine Reynolds $v$. Jamaica No. 229/1987, UN doc. A/46/40 p. 248.

${ }^{36}$ IACHR Annual Report 1984-1985, pp. 81-84 (OEA/Ser.L/V/11.66, doc.10 rev.1 (1985)). See also Sixth Report on the situation of political prisoners in Cuba (OEA/Ser.L/V/11.48, doc.7 (1979)). 
disappearance, harassment and murder of lawyers in Guatemala ${ }^{37}$, Paraguay $^{38}$ and Uruguay ${ }^{39}$.

A further question is whether by stipulating that an accused may have legal assistance of his or her own choosing, Article 6(3)(c) secures the right to an unlimited number of defence lawyers. This question was explicitly considered by the European Commission in Enslin, Baader and Raspe v. FRG. ${ }^{40}$ The applicants complained of the limitations placed by law on the number of defence lawyers on whose assistance they could call and the exclusion of certain of those lawyers. These restrictions allegedly violated Articles 6(3)(b) and (c). In its decision the European Commission explained its opinion in clear terms:

\begin{abstract}
"By stipulating that the accused may have legal assistance of his own choosing, Article 6(3)(c) does not secure the right to an unlimited number of defence lawyers. Even if the English version is more indefinite (to defend himself through legal assistance of his own choosing) the purpose of this provision is to secure that both sides of the case are actually heard by giving the accused, as necessary, the assistance of an independent professional. By stipulating the number of lawyers freely chosen by the accused to three, without prejudice to the ex officio addition of other defence counsel appointed by the court, an arrangement peculiar to the German procedural system, the authorities of the Federal Republic of Germany therefore did not violate the right secured by this provision." ${ }^{41}$
\end{abstract}

In fact, if there are cogent reasons to the effect that the complexity of the case or other reasons necessitate that the accused person be assisted by more than one lawyer, then the accused persons may so claim. But it is practically not feasible to provide as an absolute rule for the assistance of more than one lawyer particularly where the accused is provided with legal assistance under free legal aid. In Murphy v. $U K^{42}$ the applicant applied for legal aid for representation by solicitor and counsel. The European Commission came to the

\footnotetext{
${ }^{37}$ Report on the Situation of Human Rights in the Republic of Guatemala (OEA/Ser.L/V/11.53 (1981) p. 66.

${ }^{38}$ Report on the Situation of Human Rights in Paraguay (OEA/Ser.L/V/11.43 (1978) p. 71.

${ }^{39}$ Report on the Situation of Human Rights in Uruguay (OEA/Ser.L/V/11.43) p. 62. For complaints of similar nature see Report on the Situation of Human Rights in Argentina (OEA/Ser.L/V/11.49, doc.19 corr.1, 1980); Second Report on the Human Rights Situation in Suriname (OAS/Ser.L/V/11.66, doc.21 rev.1 Oct.1, 1985).

${ }^{40}$ No. 7572/76, 7586/76 and 7587/76, 21 ECHRYb 418; 14 D.R. (1978) 64.

${ }^{41}$ Ibid., p. 114.

${ }^{42}$ No. 4681/70, 43 ECHRCColl. (1972) 1 at 13.
} 
conclusion that, although the applicant was granted legal aid for counsel only, there was no indication whatsoever that he needed the help of two lawyers.

It is clear that the question of the number of lawyers does not arise where the accused has sufficient means to pay for legal representation. If the accused person asks for free legal representation, it is unreasonable to assume that the right to free legal assistance extends up to the point where accused persons can demand as of right any number of lawyers of their own choice. Such interpretation would create obstacles in the judicial process as well as in the implementation of the right to free legal assistance. The number of lawyers that can be assigned to an accused person must depend on the circumstances of each case.

\subsection{Power of the state to regulate the appearance of defence lawyers}

Since no assistance can be found in the travaux preparatoires of the ICCPR and ECHR or in the decisions of the UNHRC and the IACHR with regard to this controversial issue, one has to turn to the jurisprudence of the European Commission and the European Court.

The state's power to regulate the appearance of defence lawyers cannot be disputed in principle since one may reasonably assume that it is only for the purpose of giving effect to the blanket provisions of Article 6(3)(c) of the ECHR. It is the responsibility of the state to facilitate the effective enjoyment of the rights contained in the Convention. But a question arises when, on the pretext of regulating the effective implementation of the provisions of Article 6(3)(c), the state attempts to curtail the proper ambit of this right. This issue came up for the first time in 1962 before the European Commission in $X \mathrm{v}$. $F R G .^{43}$ The applicant was charged with committing various political crimes. $\mathrm{He}$ chose Professor C. to represent him as his attorney and he was apparently able to pay his fee. The court however, refused to allow this lawyer to represent the applicant. In examining whether there had been a violation of Article 6(3)(c), the European Commission stated:

“. . . that the right to defend himself through legal assistance of one's own choosing, as guaranteed by Article 6(3)(c) of the Convention, is not an absolute right, but limited by the right of the state concerned to make regulations concerning the appearance of lawyers before the courts. Whereas it follows that ... an examination of the case ... does not disclose any

${ }^{43}$ No. 722/60, 5 ECHRYb (1962) 104; see also X v. FRG No. 509/59, 3 ECHRYb (1959) 174. 
appearance of a violation of the rights and freedoms set forth in the Convention." ${ }^{.44}$

Although the European Commission's short decision does not give any reason why the lawyer was excluded, THOMAS BURGENTHAL ${ }^{45}$ hypothesizes the reason to be that the attorney in question was associated with the same political group as the accused.

The forgoing discussion has shown that the right of choice enjoyed by an accused person who has means to pay for a lawyer is subjected to further restrictions by the power of the state to exclude the appearance of certain lawyers. These decisions are open to criticism; a lawyer's involvement in a political association or a party is not a valid and justifiable ground for a state to use its power to exlude lawyers from appearing before the Court. However, there may be instances where the power of the state to regulate the appearance of lawyers is justifiable and reasonable. For example, the state may impose restrictions through educational or character standards or apprenticeship requirements for lawyers. ${ }^{46}$ It may also impose restrictions in order to maintain the order of Court administration and to uphold professional etiquette. ${ }^{47}$ The problem that arises in connection with the power of the state is the necessity to draw a line between acceptable regulation and unjustified interference. It is hardly possible to lay down any general rules as to how this distinction could be drawn. Since the circumstances of each case may vary, it can only be done on a case by case basis. However, when dealing with these questions, the international and regional bodies on human rights should maintain a balance between the power of the state and the rights of the accused.

\section{DIFFERENT ASPECTS OF THE RIGHT TO LEGAL ASSISTANCE}

\subsection{The right to be present at the hearing}

Bringing accused persons before the court to stand trial is a generally accepted practice in every jurisdiction. The presence of accused persons at

\footnotetext{
${ }^{44}$ Ibid., at 106.

45 'Comparative study of certain due process requirements of the European Human Rights Convention', 16 Buffalo Law Review (1966-1967) 35. See further Enslin, Baader and Raspe $v$. FRG No. 7572/76, 7586/76 and 7587/76, 14 D.R. (1978) 64 at 114.

${ }^{46}$ C.C. MORRISON, The Developing European Law of Human Rights (1967).

${ }^{47} \mathrm{X} v$. FRG No. 5217/71 and 5367/72, 42 ECHRCColl. (1972) 139; X v. UK No. 6298/73, 21 May 1975 (unpublished); X v. UK No. 8295/78, 15 D.R. (1978) 242.
} 
their trial is indispensable for the conduct of a fair trial. By conferring on the accused person a right to be present at the hearing, the law accepts that this is no longer a matter of discretion of the court. As the law formulated by the ICCPR now stands, the accused person is entitled to demand that he or she be brought before the court for the trial and only in exceptional situations and on very compelling grounds can the court tamper with this right.

Only the ICCPR guarantees the right of the accused to be tried in his or her presence. Neither the ECHR nor the ACHR secure to the accused a right to be present at the hearing. The European Commission has repeatedly affirmed this. Although there are no provisions regarding the right to be present at the trial in the ECHR, the European Commission has considered whether the exclusion of the accused from the hearing of a case constitutes a violation of Article 6(3)(c). In most of the cases that came up for consideration before the European Commission the right to be present at the trial was claimed not in respect of the trial in the proper sense but in respect of the appeal proceedings. But the case law of the European Commission does not make a distinction between the two situations. The objective view seems to be that the accused person's right to be present should be respected regardless of the nature of the proceedings and that the notion of fair trial involves not only the trial proper but also the appeal proceedings.

The European Commission has emphasized that the Court should take into account "the whole situation of the defence and not only the person of the accused". ${ }^{48}$ The rationale behind Article $6(3)(\mathrm{c})$ is that a criminal trial may not take place without the defence having the opportunity to present its arguments adequately. One can argue on a plain reading of the words, that Article $6(3)(c)$ guarantees to an accused only a right to defend himself or herself either in person or by a representative as nothing is mentioned about a right to be present in person. It is important to note that the presence of the accused at the hearing could be beneficial to the prosecution as well as the accused. For example, the presence of the accused could enable the prosecution to confront the accused with important questions relevant to the case. The circumstances of the case may also demand that the accused person be represented by a lawyer in the best interest of the accused. ${ }^{49}$

Another important question that arises in this connection is whether the accused person's presence at the trial excludes his or her right to legal

\footnotetext{
${ }^{48} \mathrm{X} v$. FRG No. 1169/61, 4 ECHRYb (1963) 520; X v. Austria No. 7138/75, 9 D.R. (1977) 50 at 53; X v. Belgium No. 2635/65, 15 Dec. 1967 (unpublished); $M v$. UK No. 9728/82, 36 D.R. (1983) 155; X v. UK No. 3852/68, 32 ECHRCColl. (1969) 38; X v. Denmark No. 8395/78, 12 March 1980 (unpublished).

${ }^{49} \mathrm{X} v$. FRG No. 5730/72, 11 Dec. 1973 (unpublished).
} 
assistance. The mental strain and pressure is immense where an accused is charged with a grave crime and where a conviction might result in death or life imprisonment. In such a situation one cannot assume that accused persons, however well informed or familiar with all the facts necessary to prepare their defence, would be able to defend themselves without the assistance of a lawyer. Therefore the courts should not prevent accused persons being represented by a lawyer merely because they can appear in person. The European Commission also stated in Pakelli v. FRG that:

“. . . both in the French and in the English text, the right to free legal assistance as the right to counsel in general is not excluded where the accused can appear in person. Indeed another interpretation would lead to a result not compatible with the object and purpose of Article 6(3)(c) because the choice of counsel and the right to free legal assistance would depend upon the non-appearance of the accused." 50

Moreover, in the case of Poitrimol v. France ${ }^{51}$ the European Court stated that a person charged with a criminal offence does not lose the benefit of this right merely on account of not being present at the trial.

The nature of the issues involved in a particular case is an important factor in deciding whether the accused has a right to be present at the hearing. If the issue before the court is purely a legal question, the issue could well be decided without the court having to obtain a personal impression of the accused. In such a situation representation through a lawyer would be sufficient. ${ }^{52}$ Conversely, if the decision of the court could result in a considerable increase of the sentence, the issues are not necessarily limited to an examination of points of law. In a situation of that nature the accused's personal appearance at the hearing is required in order to secure him or her a fair hearing within the meaning of Article 6(1) ${ }^{53}$

The accused's right to be present at the hearing is related to the principle of 'equality of arms', i.e. the procedural equality between the accused and the prosecutor. The accused and the prosecutor have an equal right to adduce evidence and to take an active part in the proceedings in court. ${ }^{54}$ The

\footnotetext{
${ }^{50}$ No. 8398/78, 24 D.R. (1981) 112 at 119-121. The European Court concurred with this view. See 64 Judgments and Decisions (1983).

51 39/1992/384/462, 23 Nov. 1993, 277 Judgments and Decisions p. 14 para. 34.

${ }^{52} \mathrm{X} v$. Austria No. $7138 / 75,9$ D.R. (1977) 50 at 53.

${ }^{53} \mathrm{X} v$. Austria No. 8289/78, 18 D.R. (1980) 160.

${ }^{54}$ Pataki and Dunshirn $v$. Austria No. 596/59 and 789/60, 4 ECHRYb (1963) 718; Ofner and Hopfinger $v$. Austria, No. 524/59, 617/59, 6 ECHRYb (1962) 322; see also X $v$. Austria No. 1135/61, 6 ECHRYb (1963) 194.
} 
European Commission reached the conclusion that if the prosecution has not played an active role at the trial, the presence of the accused is not necessarily warranted. However, the above-mentioned conclusion cannot be reconciled with the notion of fair trial. In a criminal trial, the life and liberty of persons accused may be at stake and they face a perilous situation. Therefore, they should be brought before the court or otherwise be entitled to request this. The ICCPR has gone a step further than the ECHR and it has now been established in international law that accused persons have a right to be present at a trial against them. In order to avoid the present ambiguous situation emanating from the case law of the European Commission, it is suggested that the latter should adopt the substance of Article 14(3)(c) of the ICCPR in interpreting Article 6(3)(c).

Further, it may be that the accused was not present at the trial through his or her own fault..$^{55}$ In 1994 the European Court stated in Lala v. the Netherlands that the non-appearance of the defendant, in spite of having been properly summoned, cannot, even in the absence of an excuse, justify depriving him of his right under Article 6(3) to be defended by counsel. ${ }^{56}$

The UNHRC has also stated that

"the concept of a 'fair trial' within the meaning of Article $14 \ldots$ must be interpreted as requiring the fulfilment of a number of conditions, such as equality of arms and respect for the principle of adversary proceedings. These requirements are not respected where ... the accused is denied the opportunity personally to attend the proceedings ....."57

In Daniel Monguya Mbenge v. Zaire ${ }^{58}$ a Zairean citizen was twice sentenced to capital punishment by a Zairean tribunal. The UNHRC had to examine whether the proceedings disclosed any breach of rights under the Covenant. It stated that:

\footnotetext{
${ }^{55} \mathrm{X} v$. Netherlands No. 1059/61, 5 ECHRYb (1962) 262 at 288; see also X $v$. UK No. 3075/67, 11 ECHRYB (1968) 466.

${ }^{56}$ 25/1993/420/499, 22 Sep. 1994, 297 Judgments and Decisions. The same view was adopted in Pelladoah $v$. the Netherlands, 27/1993/422/501, 22 Sep. 1994, 297 Judgments and Decisions. ${ }^{57}$ Dieter Wolf $v$. Panama No. 289/1988, UN doc. A/47/40 p. 281-282.

${ }^{58}$ No. $16 / 1977$, UN doc. A/38/40 p. 134; Touron $v$. Uruguay No. R/32, UN doc. (A/36/40) p. 120; Pietraroia $v$. Uruguay No. R. 10/44, UN doc. A/36/40 p. 153; Luciano Weinberger Weisz v. Uruguay No. R. 7/28, UN doc. A/36/40 p. 114; Conteris $v$. Uruguay No. 139/1983, UN doc. A/40/40 p. 196; Cubas Simones $v$. Uruguay No. R. 17/70, UN doc. A/37/40; Violeta Setelich v. Uruguay No. R. $14 / 63$, UN doc. A/37/40.
} 


\begin{abstract}
"Article 14(3) and other requirements of due process enshrined in Article 14 cannot be construed as invariably rendering proceedings in absentia inadmissible irrespective of the reasons for the accused person's absence. Indeed, proceedings in absentia are in some circumstances (for instance when the accused although informed of the proceedings sufficiently in advance, declines to exercise his right to be present) permissible in the interests of the proper administration of justice. Nevertheless, the effective exercise of the rights under Article 14 presupposes that the necessary steps should be taken to inform the accused beforehand about the proceedings against him. Judgment in absentia requires that, notwithstanding the absence of the accused all due notification has been made to inform him of the date and place of his trial and to request his attendance."
\end{abstract}

Trial in absentia is warranted only where the court is satisfied that the accused is wilfully absconding from the trial. Even then, as was apparent from the above decision, the judge is obliged to comply as far as possible with the rules of fair trial and to take into account the interests of the defence notwithstanding the absence of the accused. The law governing criminal procedure in many countries provides exceptions to the accused's right to be present at the trial. For example an accused can be tried in his absence where:

(a) the accused voluntarily refrains from attending the trial; 60

(b) if the accused is a mentally disturbed person; ${ }^{61}$

(c) if the accused had escaped or was not available at the time of the trial; ${ }^{62}$

(d) if the accused is suspected of a crime which is not punishable by deprivation of liberty; ${ }^{63}$

(e) if the accused attempts to disrupt the hearing and fails to desist when warned by the trial judge. ${ }^{64}$

In many jurisdictions the presence of the defence lawyer is obligatory where the trial take place in the absence of the accused.

\footnotetext{
${ }^{59}$ Ibid., p. 138.

${ }^{60} \mathrm{UK}, \mathrm{CCPR} / \mathrm{C} / 1 /$ Add .17 p. 17.

${ }^{61}$ Norway, CCPR/C/1/Add 5 p. 5.

${ }^{62}$ Yugoslavia, CCPR/C/Add.23; Italy, CCPR/C/6/Add.4.

${ }^{63}$ Russia, CCPR/C/1/Add 22 p. 16; Poland, CCPR/C/4/Add.2 p. 19.

${ }^{64}$ Netherlands, CCPR/C/10/Add.3 p. 20; Austria, CCPR/C/6/Add.7 p. 17; New Zealand, CCPR/C/10/Add.6 p. 55; Gilbert Islands, CCPR/C/1/Add.37 Annex G p. 93; Gibraltar, CCPR/C/1/Add.37, Annex F p. 65.
} 


\subsection{The right of access to a lawyer}

The right of access to a lawyer is not specifically guaranteed by the ICCPR, ECHR and ACHR. The various international and regional bodies on human rights have declared that the right of access to a lawyer, constituting an element of the right to a fair trial, is invariably connected to and can be considered as the very first step of the wider right of legal assistance. The right of access to a lawyer, though important throughout the entire proceedings, should particularly be observed during any period of detention of the accused, because especially in these circumstances the lawyer is a very important link with the outside world. It is through a lawyer that the accused person could complain about the conditions of detention or violation of his rights, institute proceedings before a court, apply for bail etc.

Golder v. UK ${ }^{65}$ was the first case under the ECHR to recognize this right. The appellant, a prisoner, had petitioned the Home Secretary for permission to consult a solicitor with a view to bringing a civil action for libel against a prison officer. His petition was refused. Both the European Commission and the European Court held that the right of access to a court or tribunal constituted an element which is inherent in the right protected by Article 6(1) of the ECHR. Both the European Commission and European Court agreed that there were no inherent limitations to the right of a convicted prisoner to institute proceedings and for that purpose to have unrestricted access to a lawyer. This right was reiterated by the European Court in Airey v. Ireland ${ }^{66}$

The UNHRC has also found violations of Article 14(3) in cases where an accused person who was detained 'incommunicado' in military establishments was barred from access to a lawyer. In the cases of William Torrez Ramirez v. Uruguay ${ }^{67}$ and Touron v. Uruguay ${ }^{68}$ the UNHRC held that the way the accused persons were treated during their detention virtually excluded any possibility of them having recourse to a legal counsel.

During its visits to the detention centers in a number of places in Haiti, the Special Commission of the IACHR heard prisoners' complaints about their lack of access to attorneys. ${ }^{69}$ The IACHR has also declared a violation of the right

\footnotetext{
${ }^{65}$ No. 4451/70, 1 EHRR (1975) 524.

${ }^{66}$ No. 6289/73 2 EHRR (1979) 305.

${ }^{67}$ No. R. 1/4, UN doc. A/35/40 p. 121.

${ }^{68}$ No. R. 7/32, UN doc. A/36/40 p. 120; see also Lafuente Penarrieta et al. v. Bolivia No. 176/1984, UN doc. A/43/40, p. 199.

${ }^{69}$ Case 1992 (Haiti), IACHR. Ten Years of Activities, 1971-1981, pp. 170-71; Case 6586 (Haiti), IACHR Annual Report 1982-1983, pp. 91-93 (OEA/Ser.L/V/11.61, Doc. 22 Rev. 1 1983); Case 3552 (Jamaica), IACHR Annual Report 1982-1983, pp. 99-100 (OEA/Ser.L/V/11.61, Doc. 22
} 
to legal assistance where the accused were arrested and detained without access to or benefit of counsel. ${ }^{70}$ The factual and legal issues involved in these cases were very similar and also straightforward. As a result the IACHR did not discuss the issues in depth and no helpful discussions are found in these decisions.

\subsection{The right to adequate time and opportunity to give instructions to the lawyer}

Once accused persons have access to a lawyer it necessarily follows that they should be afforded adequate time and opportunity to instruct their lawyer. The UNHRC has stated that it is imperative that accused individuals be afforded adequate time for the preparation of their defence. ${ }^{71}$ Unless the accused is given time to instruct the lawyer, the lawyer may not be able to prepare the defence adequately.

In Goddi v. Italy ${ }^{72}$ neither the applicant, who was in custody, nor his lawyer who had not been notified of the hearing, was present at the trial. Consequently, the court appointed a lawyer. This lawyer was not given time nor opportunity to acquaint himself with the case. The European Court declared that "the court should have adjourned or suspended its proceedings for a sufficient time to allow the new lawyer to prepare his case adequately and to consult the applicant". The failure to do so amounted to a violation of Article 6(3)(c)..$^{73}$

Murphy v. $U K^{74}$ presents a different picture. The Applicant complained of the fact that he did not obtain full legal aid at the quarter session. He claimed that, having obtained legal aid only on the day of appearance, he had insufficient time to explain the mitigating facts to counsel, who, therefore, was unable to offer a proper defence. However, the accused could have requested the court to adjourn the trial if he had felt that he was not given sufficient time to contact a lawyer. As he had made no such request, the European Commission held that the accused could not claim a violation of Article 6(3)(c). Thus

rev. 1 1983); Case 9265 (Suriname), IACHR Annual Report 1984-1985, pp. 119-121 (OEA/Ser.L/V/11.66, doc. 10 rev. 1 1985).

${ }^{70}$ Report on the situation of human rights in Haiti (OEA/Ser.L/V/11.46 doc.66 rev.1 1979); Case 9850 (Argentina) IACHR Annual Report 1990-91 (OEA/Ser.L/V/11.79/rev.1 Doc.121991) p. 41.

${ }^{71}$ Nicole Fillastre $v$. Bolivia No. 336/1988, UN doc. A/47/40 p. 294 at 298.

${ }^{72}$ No. 8966/80, 76 Judgements and Decisions (1984).

${ }^{73}$ See also Campbell and Fell $v$. UK No. 7819/77, 7878/77, 80 Judgments and Decisions (1982).

${ }^{74}$ No. 4681/70, 43 ECHRCColl. (1972) 1 at 13. 
if it is the accused person's own fault that prevents him from contacting his lawyer, he cannot claim a violation of this article. ${ }^{75}$ This case too is an example of the restrictive perception of the European Commission of the rights contained in the ECHR. The proper question to which the European Commission should have addressed itself is not whether the persons accused have asked for their rights or not, but whether the benefit of the rights conferred by the ECHR on accused persons has really accrued to them. It should be emphasized that it is incumbent upon the judge to ensure that the rules regulating a fair trial are strictly adhered to. Unless the persons accused have expressly waived the rights they are entitled to ask for, the judge must act in a way which ensures that all the steps necessary for a fair trial, including adequate time and opportunity for giving instructions to the lawyer, are observed. However, if the court has granted the accused ample time he or she cannot neglect to consult a lawyer and subsequently complain of a lack of opportunity to retain a lawyer. ${ }^{76}$

In Conteris v. Uruguay ${ }^{77} \mathrm{Mr}$. CONTERIS never saw his military-appointed counsel before the trial. It was only after the proceedings that CONTERIS had a brief meeting with him and he never heard from him again. He was sentenced to 15 years imprisonment at a trial which lasted three to four minutes. Mr. CONTERIS was unable to articulate his defence with the assistance of a lawyer who took his case seriously nor was he allowed to appear personally. In the light of these circumstances the UNHRC reached the conclusion that the state party had violated Article 14(3)(b) and (d) of the Covenant because the accused person had had no access to legal counsel for the preparation of his defence and could not defend himself in person or through legal counsel of his own choosing.

The IACHR has declared a violation of the right to a fair trial where the prisoner had the opportunity to see his lawyer for no more than 20 minutes and in the presence of the secret police. ${ }^{78}$

\footnotetext{
75 Jacob Kamma $v$. Netherlands No. 4771/71, 42 ECHRCColl. (1972) 22 at 32.

${ }^{76} \mathrm{X} v$. Austria No. 1135/61, ECHRYb (1963) 194.

${ }^{77}$ No. 139/1983, UN doc. (A/40/40) p. 196; see also Oxandabarat Scarrone $v$. Uruguay No. 103/1981, UN doc. A/39/40 p. 154; Almirati Nieto $v$. Uruguay No. 92/1981, UN doc. A/38/40 p. 201.

${ }^{78}$ Case 10.198 (Nicaragua), IACHR Annual Report 1989-1990 p. 96 (OEA/Ser.L/V/11.77 rev. 1 Doc. 7).
} 


\subsection{The right to communicate with counsel and the maintenance of secrecy of such communication}

The right of an accused person to communicate with counsel is specifically guaranteed in Article 14(3)(b) of the ICCPR which reads: "To have adequate time and facilities for the preparation of his defence and to communicate with counsel of his own choosing." Unlike the ICCPR and the ACHR, the ECHR does not expressly secure this right. However, the case law of the European Commission and the European Court has rectified this omission. In the absence of an express provision in the ECHR, the European Commission has considered most applications concerning a violation of this right under Article 6(3)(b). The European Court observed in $S$ v. Switzerland ${ }^{79}$ that an accused's right to communicate with his advocate is part of the basic requirement of a fair trial in a democratic society and follows from Article 6(3)(c) of the Convention. The Court was of the view that if a lawyer was unable to confer with his client and receive confidential instructions from him without surveillance, his assistance would lose much of its usefulness.

As mentioned earlier, the right to legal assistance extends to the whole proceeding. Being an ingredient of this right, it is obvious that the right to communicate with counsel also applies to the preliminary investigation stage. ${ }^{80}$

The question may be raised whether the accused has a right to communication in private. It is accepted practice in countries with a modern legal system that communication between a lawyer and a client entails confidentiality. Generally speaking, defence counsel cannot fulfil their tasks properly if they are not allowed to communicate with their clients in private, and reversely, all those rights conferred on accused persons which are essential for the conduct of a fair trial would be meaningless if accused persons could not communicate with their counsel confidentially. Though the right to communicate with their counsel in private is not expressly guaranteed by the ICCPR, the UNHRC has admitted this right in its 'General Comments' under Article 40 in the following terms:

"Article 14(3)(b) requires counsel to communicate with the accused in conditions giving full respect for the confidentiality of their communications. Lawyers should be able to counsel and to represent their clients in accordance with their established professional standards and judgements without any

\footnotetext{
${ }^{79}$ 48/1990/239/309-310, 220 Judgments and Decisions para. 48; Bonzi v. Switzerland No. 7854/77, 12 D.R. (1978) 185 at 190.

${ }^{80}$ Can $v$. Austria No. 9300/81, 96 Judgments and Decisions (1985).
} 
restrictions, interferences, pressures or undue interference from any quarter." ${ }^{, 81}$

Although this issue has not yet come before the UNHRC by way of individual application, the comment clearly shows that the UNHRC has accepted that the right to communicate with counsel as provided for by the ICCPR does not end there, but encompasses the right to communicate in private. The UNHRC's view, it is submitted, is the correct view, if the right to a fair trial in general and the right to legal assistance in particular are to be effective.

Can it be said that the right to communicate with counsel confidentially is without any restriction or exception? There may be instances where a restrictive interpretation is called for, due to exceptional circumstances. For example, there may be instances where very serious matters of national security, international terrorism, drug trafficking etc. are involved. ${ }^{82}$ For example, exceptions have been introduced in Germany in conjunction with combatting terrorism. The representative of Germany explained to the UNHRC that these restrictions were introduced when it became clear in various cases that lawyers had been using their visits as defence counsel to serve as messengers between individual members of a terrorist organization, thus promoting the perpetration of further acts of violence in some cases and even smuggling weapons into the prison. Any restriction in this respect must remain an exception to the general rule, and therefore must be justified by the circumstances of the case. Several decisions of the European Commission and the European Court seem to accommodate this justification. ${ }^{83}$

For the sake of completeness, attention may be drawn to the decisions of the UNHRC, even though these are significantly less informative and less fully argued than the decisions of the European Commission and the European Court. In Cubas Simones v. Uruguay, ${ }^{84}$ Lanza v. Uruguay, ${ }^{85}$ D. Marais v. Madagascar, ${ }^{86}$ and Maner Lluberas v. Uruguay, ${ }^{87}$ although the accused

\footnotetext{
${ }^{81} \mathrm{UN}$ doc. A/39/40.

${ }^{82}$ Bonzi v. Switzerland No. 7854/77, 12 D.R. (1978) p. 185 at 190-191; Schertenleib $v$. Switzerland No. 8339/78, 17 D.R. (1979) p. 180; Krocher and Moller v. Switzerland No. 8463/78, 26 D.R. (1981) p. 24; No. 9370/81 G. v. UK, 35 D.R. (1983) p. 75; Can v. Austria No. 9300/81, 96 Judgments and Decisions (1985).

${ }^{83}$ Bonzi $v$. Switzerland No. 7854/77, 12 D.R. (1978) p. 185 at 190; Schertenleib $v$. Switzerland, No. 8339/78, 17 D.R. (1979) p. 180; Can v. Austria No. 9300/81, 96 Judgments and Decisions (1985).

${ }^{84}$ No. R. 17/70, UN doc. A/37/40 p. 174.

${ }^{85}$ No. R. $2 / 8$ UN doc. A/35/40 p. 111.

${ }^{86}$ No. $49 / 1979$, UN doc. A/38/40 p. 141.

${ }^{87}$ No. 123/1982, UN doc. (A/39/40) p. 175.
} 
were provided with ex officio counsel, they were not given a single opportunity to communicate with their counsel. Therefore the UNHRC declared a violation of Article 14(3)(b) of the ICCPR. The UNHRC did not provide any detailed discussions of the right to communicate with counsel in any of these cases.

Similarly, in case 3096 (Haiti) $^{88}$ the IACHR held that there had been a violation of the right to a fair trial where the accused had not been allowed to communicate with his defence attorneys since being in jail. The IACHR has also received information that Panamanian officials often interfere with the defendant's access to his lawyer, one of the notorious cases being that of Dr. JOSE MANUEl FAUNDES, a defence attorney of Panama City. The interference with Dr. FAUNDES's access to his clients had allegedly reached the point that a sign had been posted in the prison to the effect that prisoners would not be permitted visits from Dr. FAUNDES. ${ }^{89}$

\subsection{The right to free legal assistance where the accused does not have means to pay for a lawyer}

The right of an accused person to legal assistance has little or no meaning if no proper steps are taken to provide the means which enable the effective exercise of the right conferred by Articles 14(3)(d), 6(3)(c) and 8(2)(d) and (e) of the ICCPR, ECHR and ACHR, respectively. In a global context, most accused persons involved in criminal proceedings would undoubtedly be the underprivileged. They may be impoverished or belong to the lower social strata, and the right to free legal assistance is therefore of vital significance for them.

According to the ICCPR and the ECHR, the entitlement to the right to free legal assistance depends on two conditions: the accused is without means to pay for a lawyer and the interests of justice so require. Unless persons accused can prove the fulfilment of these conditions, they are precluded from the benefit of this privilege. ${ }^{90}$ In determining whether the accused is without

\footnotetext{
${ }^{88}$ IACHR Annual Report 1982-1983 pp. 87-89 (OEA/Ser.L/V/11.66 doc. 10 rev. 1 1985). See also Case No. 8094, 9038 and 9080 (Guatemala), LACHR Annual Report 1984-1985, pp. 81-84 (OEA/Ser.L/V/11.66 doc. 10 rev. 1 1985); Case 9850 (Argentina), LACHR Annual Report 19901991, p. 41 (OEA/Ser.L./V/11.79 rev. 1 Doc. 12).

${ }^{89}$ Report on the situation of human rights in Panama (OEA/Ser.L/V/11.44/ doc. 38 rev. 1 (1978). ${ }^{90} \mathrm{X} v$. Austria No. 833/60, 3 ECHRYb (1960) p. 428 at 440; X $v$. FRG No. 604/59, 3 ECHRYb (1960) p. 236 at 242; X v. FRG No. 599/59, 8 ECHRCColl. (1961) p. 12; X v. UK No. 5477/72, 9 Feb. 1973 (unpublished); X v. FRG No. 2703/66, 3 April 1967 (unpublished); X $v$. UK No. 3104/67, 7 Oct. 1967 (unpublished); X v. UK No. 5881/72, 11 Dec. 1973 (unpublished); $\mathrm{X} v$. FRG No. 3049/67, 15 July 1968 (unpublished).
} 
means or not, most countries apply the 'financial means test' 91 and 'reasonableness test ${ }^{\prime 2}$ which take into account the net income per annum and the liquid assets of the accused person. In some countries the accused is required to submit a 'certificate of means'. ${ }^{93}$

The wording of the ACHR is somewhat different. According to Article 8(2) an accused person is entitled to be assisted by counsel provided by the state, paid or not as the domestic law provides, in two instances: if the accused person does not engage in defence personally nor engage his or her own counsel within the period established by law. The Inter-American Court of Human Rights has interpreted the wording of this provision in one of its advisory opinions, as follows:

"25. (. . .) In cases where the accused neither defends himself nor engages his own counsel within the time period established by law, he has the right to be assisted by counsel provided by the state, paid or not as the domestic law provides. To that extent the Convention guarantees the right to counsel in criminal proceedings. But since it does not stipulate that legal counsel be provided free of charge when required, an indigent would suffer discrimination for reason of his economic status if, when in need of legal counsel, the state were not to provide it to him free of charge.

26. Article 8 must, then be read to require legal counsel only when that is necessary for a fair hearing.

Any state that does not provide indigents with such counsel free of charge cannot, therefore, later assert that appropriate remedies existed but were not exhausted.

27. Even in those cases in which the accused is forced to defend himself because he cannot afford legal counsel, a violation of Article 8 of the Convention could be said to exist if it can be proved that the lack of legal counsel affected the right to a fair hearing to which he is entitled under that Article." ${ }^{94}$

The most important question with regard to the right to free legal assistance is whether the state is under an obligation to provide a lawyer without a fee in all circumstances whenever an accused person has no means

\footnotetext{
${ }^{91}$ E.g. New South Wales, Spain, Sri Lanka.

${ }^{92}$ South Australia, The Philippines etc.

${ }^{93}$ E.g. Canada (Ontario); see also Pakelli $v$. FRG, 64 Judgments and Decisions p. 21.

${ }^{94}$ Advisory Opinion OC-11/90 10 Aug. 1990, Exceptions to the Exhaustion of Domestic Remedies, 11 Judgments and Opinions p. 28.
} 
to pay for a lawyer. Before examining the actual practice of states in this regard, it is important to examine the scope of the three instruments. The main limitation imposed upon the right in question in all three instruments is that the right to free legal assistance is only specifically guaranteed in respect of criminal cases..$^{95}$ This is apparent from the words "Everyone charged with a criminal offence" and "Every person accused of a criminal offence".

The right to free legal assistance includes representation in court as well as legal advice. Many countries provide legal advice to clients free of charge regardless of the offence involved. ${ }^{96}$ The problem facing many countries in providing legal assistance in all circumstances is the lack of funds for legal aid counsel. The problematic issues involved in developing countries such as India were exemplified by the representative of India at the eleventh session of the UN Economic and Social Council:

"The application of such a provision in India for example where a minor magistrate might deal with up to five thousand persons a year, would be ruinous to the administration and financial stability of the country."97

Therefore in many jurisdictions legal aid is not as fully available in respect of non-indictable offences, i.e. less serious offences, as it is in regard to indictable offences. As a result some states have made reservations to the ICCPR, to the effect that free legal aid for accused persons is limited to persons charged with capital offences. ${ }^{98}$ In some instances accused persons are required to contribute towards the cost of legal aid counsel according to their means. ${ }^{99}$

On a careful scrutiny of the case law of the European Commission and the European Court several observations can be made on the scope of the right to free legal assistance. In order to provide maximum benefit to the accused person, the right to free legal assistance must be practical and effective. The case of Artico v. Italy ${ }^{100}$ illustrates this point very well. In this case, Mr. ARTICO was assigned a lawyer under free legal aid who withdrew later due to

\footnotetext{
${ }^{95} \mathrm{E} / \mathrm{Ac} .7 / \mathrm{SR} .149$.

${ }^{96}$ E.g. New South Wales, South Australia, Austria, Canada, Indonesia etc. See further: International Bar Association, International Directory of Legal Aid (1985).

${ }^{97}$ E/AC.7/SR.149.

${ }^{98}$ E.g. Gambia and Australia.

${ }^{99}$ United Nations Multilateral Treaties Deposited with the Secretary General (1987) 129; Reservation deposited by Switzerland in respect of the ECHR, in: Council of Europe, Collected Texts of the European Convention of Human Rights (1986); see also UK, CCPR/C/1/Add. 17 p. 17; Poland, CCPR/C/S.190 p. 10; Hungary, CCPR/C/S.686.

${ }^{100}$ No. 6694/74, 34 Pleadings (1979). See also No. 10098/82 v. Germany.
} 
other commitments. Mr. ARTICO repeatedly requested another lawyer without success. The European Commission observed that Article 6(3)(c) not only guarantees the right to an adequate defence either in person or through a lawyer, but also reinforces this by an obligation on the part of the state to provide free legal assistance. Mr. ARTICO claimed to be a victim of a breach of this obligation. The government, on the other hand, regarded the obligation as satisfied by the nomination of a lawyer for legal aid purposes. The decisions of the European Court acted as buttress of this right:

\begin{abstract}
"[. . .] the Convention is intended to guarantee not rights that are theoretical or illusory but rights that are practical and effective [. . .]. As the Commission's delegate correctly emphasized article 6(3)(c) speaks of 'assistance' and not of 'nomination'. Again mere nomination does not ensure effective assistance, since the lawyer appointed for legal aid purposes may die, fall seriously ill, be prevented for a protracted period from acting or shirk his duties. If they are notified of this situation the authorities must either replace him or cause him to fulfil his obligations. Adoption of the government's restrictive interpretation would lead to results that are unreasonable and incompatible with both the wording of sub paragraph (c) and structure of Article 6 taken as a whole, in many instances free legal assistance might prove to be worthless." 101
\end{abstract}

This point was reiterated in the Kamasinski Case $^{102}$ where the European Court stated that the appointment of a legal aid lawyer does not necessarily ensure compliance with Article 6(3) although the state cannot be held responsible for every shortcoming of the lawyer. However, it further stated that competent national authorities are required to intervene only if failure by the legal aid lawyer to provide effective representation is manifest and sufficiently brought to their attention.

The UNHRC has also considered the qualitative aspect of an assigned counsel in Pratt and Morgan v. Jamaica ${ }^{103}$. The Committee expressed the view that:

"[a]lthough persons availing themselves of legal representation provided by the State may often feel they would have been better represented by a counsel of their own choosing, this is not a matter that constitutes a violation

\footnotetext{
10137 Judgments and Decisions (1980) p. 16. See also Goddi $v$. Italy No. 8966/80, 6 EHRR (1984) 457; Biondo $v$. Italy No. 8821/79; Stock Taking on the European Convention, Supplement 1985, p. 81-82.

102 9/1988/153/207, 19 Dec. 1989, 168 Judgments and Decisions.

${ }^{103}$ UNHRC 44 (A/44/40) p. 222.
} 
of Article 14(3)(d) by the State Party. Nor is the Committee in a position to ascertain whether the failure of Mr. Pratt's lawyer to insist upon calling the alibi witness before the case was closed was a matter of professional judgment or of negligence." 104

However, there might be exceptional cases where the requirements of an effective defence would require a court or tribunal to intervene and replace an assigned counsel who was clearly incapable of effectively representing a defendant. ${ }^{105}$

The present right is also an essential element of the principle of 'equality of arms' between the accused and the prosecution. Where the prosecution undoubtedly has ample legal assistance, the accused should not be precluded from such assistance and, for the strict maintenance of the equality of arms, should be provided with free legal assistance when necessary. However, if the 'inequality of arms' is attributable to the accused's own behaviour, then the accused cannot claim that he or she was not given adequate legal assistance. ${ }^{106}$

Where the case in question is not of a complicated nature and the accused can engage in personal defence, the court can refuse a request for a legal aid counsel. ${ }^{107}$ But on the other hand, where the services of a lawyer are essential in the interest of the accused person, the court cannot refuse a request for free legal aid counsel. ${ }^{108}$

The question of paying the costs of the officially appointed defence counsel has resulted in serious problems. One of the questions that arises is whether the court may order the accused persons who have been granted legal aid to reimburse the costs of the proceedings after their conviction. In $X \mathrm{v} . F R G^{109}$ the applicant complained that, having been convicted in criminal proceedings, he had been ordered to pay the costs of these proceedings and therefore was faced with the consequences of a claim which had been granted. He argued that he had a right under Article 6(3)(c) of the ECHR to free legal assistance once and for all. The wording "has not sufficient means to pay" does not, in

\footnotetext{
${ }^{104}$ Ibid., para. 13.2.

${ }^{105}$ Pinto $v$. Trinidad and Tobago, UN doc. A/45/40 p. 69 at 73 (para. 12.5). See also Reid $v$. Jamaica, ibid., p. 85 at 91 (para. 11.4).

${ }^{106} \mathrm{X} v$. UK, No. 8386/78, 21 D.R. (1980) p. 126.

${ }^{107} \mathrm{X} v$. FRG, No. 3049/67, 15 July 1968 (unpublished); X v. FRG, No. 7300/75, 12 Dec. 1976 (unpublished); $X v$. Norway, No. 8202/78, 7 May 1979 (unpublished).

108 Glase $v$. Austria No. 834/60, 4 ECHRYb (1963) p. 140.

${ }^{109}$ No. 9365/81, 28 D.R. (1982) p. 229; see further P $v$. Switzerland, No. 9419/81, 33 D.R. (1983) p. 153.
} 
the European Commission's opinion, refer solely to the moment when the court decided whether or not free legal assistance should be provided. It is relevant also at the time when the question is decided whether and to what extent the defendant has to pay the costs of the proceedings. For these reasons the European Commission decided that "it is not contrary to Article 6(3)(c) that the accused has to pay the costs of his legal aid counsel after final conviction unless his means are insufficient". It is clear from the important qualification "unless his means are insufficient" in the judgment, that it was not the original intention of the European Commission to make the accused persons pay the legal costs regardless of their financial situation.

In the case of E.B. v. Jamaica (No. 303/1988) with regard to the practical operation of the system of legal aid in Jamaica, the UNHRC stressed that Article 14(3)(d) of the Covenant requires states parties to ensure proper legal assistance to persons accused of criminal offences at all stages of their trial and appeal including the Judicial Committee of the Privy Council. ${ }^{110}$

\subsection{The right to have legal assistance assigned if the interests of justice so require}

In certain instances the interests of justice necessitate the assignment of lawyers by the state. There may be instances where persons accused, owing to their involvement in a political offence, are unable to get legal assistance. The complexity of such a case may also deter lawyers from taking them up. Lawyers may also refuse to take up a case as a mark of solidarity when the victim of the crime is also a lawyer.

It was only in 1991 that the European Court considered the meaning of the words 'interests of justice'. In the case of Quaranta v. Switzerland ${ }^{111}$ the Court was of the opinion that sub-paragraph (c) of Article 6(3) attaches two conditions to this right. The first is lack of "sufficient means to pay for legal assistance" and the second is "interests of justice". The Court further stated that, in order to determine whether the "interests of justice" required that the applicant received free legal assistance, the Court had to consider the following criteria: firstly, the seriousness of the offence and the severity of the sentence risked; secondly, the complexity of the case; and thirdly, the personal situation

\footnotetext{
${ }^{110}$ No. $303 / 1988$, UN doc. A/46/40 p. 278; see also Z.P. v. Canada No. $341 / 1988$, UN doc. A/46/40 p. 297; W.W. v. Jamaica No. 254/1987, UN doc. A/46/40 p. 271 .

111 23/1990/214/270, 24 May 1991, 205 Judgments and Decisions; see also Pham Hoang $v$. France, 66/1991/318/390, 25 Sep. 1992, 243 Series A: Judgments and Decisions 22-23.
} 
of the applicant. A decision refusing legal aid should be susceptible to review, particularly if it becomes apparent at a later stage in the proceedings that the interests of justice require the provision of legal aid. In Granger v. $U K^{112}$, legal aid was refused for an appeal which was considered to have no reasonable prospect of success. At the hearing of the appeal, it became apparent that a question of law of some difficulty in fact arose. The European Court held that it would have been in the interest of justice for legal aid to have been available from that point on, and that in the absence of any review of the original decision there had been a breach of Article 6(3)(c).$^{113}$

The UNHRC has also interpreted the scope of the Article 14(3)(d) of the ICCPR which stipulates that everyone shall have "legal assistance assigned to him, in any case where the interests of justice so require". In Robinson v. Jamaica $^{114}$ the UNHRC examined the question whether a state party is under an obligation to make provision for effective representation by counsel in a case concerning a capital offence, should the counsel who was selected by the author for whatever reason decline to appear. The UNHRC believed that

\begin{abstract}
"it is axiomatic that legal assistance be available in capital cases. This is so even if the unavailability of private counsel is to some degree attributable to the author himself, and even if the provision of legal assistance would entail an adjournment of proceedings. This requirement is not rendered unnecessary by efforts that might otherwise be made by the trial judge to assist the author in handling his defence in the absence of counsel."
\end{abstract}

In the view of the Committee, the absence of counsel constituted an unfair trial.

\title{
5. CONCLUSION
}

A close examination of the provisions relating to the right to legal assistance contained in the three Conventions revealed a number of similarities and disparities. Though prima facie this right appears to be simple and straightforward, a deeper analysis demonstrated that it involves various complex legal issues. The travaux preparatoires of the three Conventions, the

\footnotetext{
11228 March 1990, 174 Judgments and Decisions, p. 17.

${ }^{113}$ See also Maxwell $v$. the United Kingdom No. 31/1993/426/505, 28 Oct. 1994, 300 Judgments and Decisions; Boner $v$. the United Kingdom No. 30/1993/425/504, 28 Oct. 1994, 300 Judgments and Decisions.

${ }^{114} \mathrm{UN}$ doc. A/44/40 p. 210.
} 
case law of the European Commission, the European Court, the UNHRC, the IACHR and the Inter-American Court of Human Rights and the various reports submitted to the Convention institutions by states parties were of considerable assistance in resolving the ambiguities in the Conventions and in obtaining a better understanding of the right to legal assistance.

The international and regional bodies on human rights have to be very cautious in expressing opinions on issues where no guidance can be obtained from the Convention provisions and the travaux preparatoires. In so doing they should not give vague and imprecise interpretations as this would increase the possibilities of abuses of the right. On the other hand, if the rights of the accused cannot be safeguarded to their maximum extent by giving a literal meaning to the Convention provisions, the international and regional bodies should seek ways and means of interpreting those provisions in a broader sense in order to give the accused a fair trial.

On the whole it is fair to say that the European Commission and the European Court have achieved a considerable success by pronouncing detailed, elaborate and lengthy decisions on the right to legal assistance. The constant and regular submission of reports and evidence by the respondent States to the European Commission and the European Court have significantly contributed to this success. In contrast, the decisions of the UNHRC and the IACHR contain very little in the way of informative or detailed legal arguments or discussion. This is because the UNHRC and the IACHR often had to consider the applications ex parte without any cooperation from the respondent governments.

The role of the lawyer has been described by the European Commission as the "watch dog of procedural irregularity". ${ }^{115}$ The absence of legal assistance affects the position of the defence at the trial and thus also the outcome of the proceedings. Therefore, the importance of guaranteeing this right to an accused person from the time of arrest, throughout the trial and appeal is self-evident.

115 Nos. 7572/76, 7586/76 and 7587/76. 